\title{
Identification of wheat varieties with high grain protein and gluten content
}

\author{
D-r.F. Askhadullin ${ }^{1 *}$, D-l.F. Askhadullin ${ }^{1}$, N.Z. Vasilova ${ }^{1}$, E.V. Zuev' ${ }^{2}$ I.I. Khusainova ${ }^{1}$, M.R. Tazutdinova ${ }^{1}$, E.Z. Bagavieva ${ }^{1}$ \\ 1 Tatar Scientific Research Institute of Agriculture, FRC Kazan Scientific Center RAS, Kazan, Russia \\ ${ }^{2}$ FRC N.I. Vavilov All-Russian Institute of Plant Genetic Resources (VIR), Saint-Petersburg, Russia
}

DOI 10.18699/ICG-PlantGen2019-03

(c) Autors, 2019

*e-mail: trulik@ya.ru

\begin{abstract}
Single examples of the creation of commercial varieties of soft wheat combining high potential productivity and grain quality indicate a strong conjugation of these systems. There is a limit to the increase in protein and gluten in soft wheat, the main elements of grain quality. One of the ways to solve this problem can be the search for and active involvement in the hybridization of samples characterized by high protein and gluten content. The paper reveals genotypes between Triticum species which are characterized by an increased content of these indicators over a number of years with different weather conditions.
\end{abstract}

Key words: Triticum; protein and gluten content in grain; productivity.

\section{Introduction}

Despite the creation of a number of varieties of soft wheat combining high grain productivity and high grain quality, there are limitations on increasing protein and gluten contents. The initial plant material plays a key role in the efficiency of selection for grain quality. Screening of the VIR wheat collection grown in the forest-steppe zone of the Republic of Tatarstan revealed varieties with the highest protein and gluten content. They can serve as a starting material for the selection of high-quality varieties of soft wheat.

\section{Materials and methods}

Cultivation of wheat varieties was preformed in 2016-2018 on TatSRIA's experimental fields in the north of the Middle Volga Region, in the Republic of Tatarstan, Russia. The soil was gray-forest, well cultivated. The weather conditions during research were typical of the forest-steppe zone, with frequent summer droughts every year except 2017, when the rainy and cold summer resulted in prolonged vegetation. Collection nurseries were established in accordance with classical methods of soft spring wheat selection. Wheat cultivation technology was traditional for the zone.

The protein and gluten contents in the grain were assessed using an Infratec 1275 infrared analyzer (FOSS). The NIR analyzer is not an absolutely accurate device, but it allows mass analysis. We have investigated the wheat varieties provided by the All-Russian Institute of Plant Genetic Resources (VIR) as well as genotypes received through institute exchange. Plant material consists of T. aestivum L. (278 varieties), T. durum Desf. (27 varieties), T. dicoccum (Schrank) Schuebl. (15 varieties), T. polonicum L. (3 varieties).

\section{Results and discussion}

The Middle Volga Region belongs to the areas where it is possible to guarantee the production of high quality wheat (Flaksberger, 1938; Vasilova, Askhadullin D-1., Askhadullin D-r., 2016). The genotype of the variety plays a key role in the gross production of high-quality wheat. The highyielding varieties of strong wheat created and recommended for cultivation in the Republic have limitations on increasing the protein and gluten content regardless of the cultivation technology. But there are reserves for increasing protein in grain in soft wheat while maintaining high productivity (Mitrofanova, Khakimova, 2016). Active use, in hybridization, of samples within the genus Triticum characterized by high protein content will increase the likelihood of creating highly productive varieties of spring wheat with protein content at the level of the best samples.

The samples of T. aestivum $\mathrm{L}$. available to us are diverse in protein and gluten content in grain. In high-protein samples. protein content in grain ranged from 14.7 to $18.7 \%$, gluten in grain from 32.8 to $38.1 \%$ (see Table 1). Collection of protein per unit area is the most important indicator of the effectiveness of breeding. Wheat cultivars Pamyati Maistrenko (K-65448, Russia, Omsk region) and Manu (K-66029, Finland) were the best samples on this indicator.

Protein and gluten levels of other tested species:

T. durum Desf. is widely used in hybridization with soft wheat and can be a source of high protein content. The maximum protein content was $16.4 \%$ in the sample of Bezenchukskaya 182 (K-59890, Russia, Samara region), while in other tested samples this measure did not exceed $15 \%$. The T. dicoccum (Schrank) Schuebl. species are high in protein. High-protein commercial varieties were created by hybridization with T. dicoccum (Lillian, Canada, etc.). Protein content in some samples reached $18.2 \%$, while the starch content was slightly lower than that of high-quality spring wheat. For protein content, K-7530 (Russia, Ulyanovsk region), K-10456 (Russia, Tatarstan), and K-21961 (Germany) stand out.

Noteworthy is the use of interspecific crosses with $T$. polonicum $\mathrm{L}$. The protein content of $T$. polonicum L. reached $17.8 \%$. The maximum protein and gluten content was in K-9277 (Israel) and Koko (K-62974, Syria) (see Table 2).

\section{Conclusions}

These data indicate a high level of protein and gluten in the species tested. Not a large set of samples can give a false result, but the use of samples of different origin levels it out. 
Table 1

Characteristics of the best T. aestivum samples by protein and gluten content in grain, 2016-2018

\begin{tabular}{lllll}
\hline № cat. VIR & Sample & Protein content in grain, $\%$ & Gluten content in grain, \% & Collecting $\mathrm{protein,} / \mathrm{m}^{2}$ \\
\hline 65478 & Krasnoufimskaya110, RUS: Sverdlovsk & 15.7 & 34.9 & 36.8 \\
65477 & Ekaterina, RUS: Sverdlovsk & 15.2 & 34.1 & 48.3 \\
65448 & Pamyati Maistrenko, RUS: Omsk & 15.0 & 33.7 & 60.0 \\
64856 & Polyushko, RUS: Novosibirsk & 14.7 & 33.3 & 47.9 \\
65473 & Long Fu 12, China & 15.9 & 35.0 & 40.4 \\
64977 & ACTaho, Canada & 15.9 & 34.2 & 45.0 \\
66203 & Lillian, Canada * & 18.7 & 37.5 & 25.8 \\
66204 & Lovitt, Canada * & 18 & 38.1 & 20.9 \\
66033 & Molera, Switzerland ** & 16.5 & 36.9 & 59.1 \\
66029 & Manu, Finland ** & 16 & 35.75 & 65.8 \\
65851 & Mayon 1, Syria ** & 15.9 & 36.15 & 30.8 \\
\hline
\end{tabular}

* tested only in 2018, ** tested in 2017-2018

Table 2

The limits of protein content and gluten in the samples tested, 2016-2018

\begin{tabular}{|c|c|c|}
\hline Species & Protein content of grain, \% & Gluten content in grain, $\%$ \\
\hline T. durum Desf. & $\begin{array}{l}\operatorname{Lim} \\
11.9-16.4\end{array}$ & $\begin{array}{l}\operatorname{Lim} \\
22.7-35.7\end{array}$ \\
\hline T. dicoccum (Schrank) Schuebl. & $\begin{array}{l}\operatorname{Lim} \\
13.2-18.2\end{array}$ & $\begin{array}{l}\operatorname{Lim} \\
24.9-29.8\end{array}$ \\
\hline T. polonicum L. & $\begin{array}{l}\operatorname{Lim} \\
14.2-17.8\end{array}$ & $\begin{array}{l}\operatorname{Lim} \\
31.2-37.8\end{array}$ \\
\hline
\end{tabular}

The source of high content continues to be T. aestivum L., but in crossing programs, despite some difficulties, you can use other high-protein species.

\section{References}

Flaksberger, C.A. Wheats, State agricultural publishing company, Moscow; Leningrad, 1938.

Vasilova N.Z., Askhadullin D1.F., Askhadullin Dr.F. et al. Formation of grain quality of spring soft wheat varieties. Achievements Science Technology AICis. 2016:30(11):42-44.
Mitrofanova O.P., Khakimova A.G. New genetic resources in wheat breeding for an increased grain protein content. Vavilovskii Zhurnal Genetiki $i$ Selektsii = Vavilov Journal of Genetics and Breeding. 2016;20(4):545-554. DOI 10.18699/VJ16.177 (in Russian).

Acknowledgements. This research was supported by FASO Russia project AAAA-A18-118031390148-1.

Conflict of interest. The authors declare no conflict of interest. 